\title{
Public good provision under dictatorship and democracy
}

\author{
Robert T. Deacon
}

Received: 6 March 2007 / Accepted: 18 December 2008 / Published online: 13 January 2009

(C) The Author(s) 2009. This article is published with open access at Springerlink.com

\begin{abstract}
The allocation of a government budget between a public good and transfers is modeled under different systems of government. The relatively even distribution of political power among groups in a democracy favors spending on nonexclusive public goods. The more concentrated pattern of political power in a dictatorship favors spending on transfers targeted to powerful groups. The hypothesis on public good provision is examined using cross-country data on public good provision and empirical indicators of political regime. Dictatorial governments are found to provide public schooling, roads, safe water, public sanitation, and pollution control at levels far below democracies.
\end{abstract}

Keywords Dictatorship and democracy · Public good provision · Governance

JEL Classification H4 · D7 · Q2

\section{Introduction}

Under dictatorship political power is concentrated among a small fraction of the population, while democracy spreads political influence more evenly. Dictatorship has been the dominant form of government over the long sweep of history (Magalhaes 1995: 546). Dictatorship and less extreme forms of nondemocratic governance remain empirically important today. Judging by Polity scores, $68 \%$ of the world's countries were governed by nondemocratic regimes during the last half of the $20^{\text {th }}$ century and over one-third remained nondemocratic as of 2000. ${ }^{1}$ Over the period 1970-1997, roughly half of the world's countries in any given year did not have legislatures that exercised significant power vis a vis the executive

\footnotetext{
${ }^{1}$ The percentage in the text refers to country-year observations and the criterion for 'dictatorship' is a Polity score (described later) below 0.5. The following comparisons use data from Banks (1997), Marshall and Jaggers (2000) and sources described later.
}

R.T. Deacon $(\bowtie)$

Department of Economics, University of California, Santa Barbara, Santa Barbara, CA 93106, USA

e-mail: deacon@econ.ucsb.edu 
and $44 \%$ either prohibited political activity or restricted it to a single official party. Democracy may appear more common than it is in fact because many nondemocratic governments permit elections and other trappings of democracy. During 1950-2000 over half of all nondemocratic countries 'elected' their chief executives and over $70 \%$ elected their legislatures. Whether by limiting ballot choices, rigging election results, or dominating those who were elected, the political elite in these countries permitted voting without relinquishing power.

All nondemocratic governments supply public goods such as roads, police, public schools and sanitation. While comprehensive empirical evidence is scarce, low public good provision often seems to accompany nondemocratic rule. For example, countries that either lack a legislature or have only a rubber stamp body enroll only $20 \%$ of their school age populations in secondary school; countries with effective legislatures enroll $81 \%$. Public good quality sometimes declines when dictatorship is imposed and improves when it is replaced. After Nigeria came under military rule in 1983, childhood disease immunization rates fell by more than one-half; in Argentina the rural population's access to safe water increased sharply after the establishment of civilian rule in 1973 (Lake and Baum 2001: 587, 588).

There is now an extensive empirical literature on public good provision under different forms of democracy. Variations in public good levels have been linked to differences in methods of apportioning votes, to parliamentary versus presidential separation of powers, to term limits for incumbents, to voter registration rules, and to other factors. Curiously, the more dramatic institutional differences separating democracy from nondemocratic rule have received far less attention. The present paper helps fill this gap by providing empirical evidence on the link between political regime and provision of specific public goods.

In what follows, political regimes are characterized by the size of the group controlling power relative to the population. The two extremes are dictatorship, rule by a single individual, and ideal democracy, where the entire citizenry shares power. While the extremes are seldom observed in practice, the terms dictatorship and democracy are used as convenient labels to describe less versus more inclusive regimes. The link between political regimes and public good provision has a straightforward intuition. In a dictatorship, where political influence is concentrated, a rational government leader will spend the public budget mainly on transfers targeted to politically influential groups. Spending on a nonexclusive public good is unwise because much of a public good's benefit would spill over to non-influential outsiders. In a democracy, where control of the government requires satisfying a large fraction of the population, direct transfers are relatively unattractive because the large size of the group whose support must be won dilutes the benefit each member receives. Spending heavily on the public good makes sense in this circumstance, due to the economies of scale inherent in supplying a public good to a larger population. A model developed later formalizes this intuition. ${ }^{1}$ Further, it traces the form of the political regime in place to two factors, the distribution of political power and degree of preference homogeneity among groups in society.

A key requirement for empirical analysis is to identify political regimes in an appropriate way. To ensure that any results generated are not simply artifacts of a particular governance measure, three alternative methods for identifying regimes are examined. The first relies on a nation's Polity index, a standard measure of governance that ranges from 0 (dictatorial)

\footnotetext{
${ }^{1}$ This basic intuition on the relative size of the controlling group underlies the comparative political models of Bueno de Mesquita et al. (2003) and McGuire and Olson (1996) and similar reasoning drives predictions on public good provision in Milesi-Ferretti et al. (2002) and Lizzeri and Persico (2004). In Persson and Tabellini's $(1999,2000)$ models of presidential versus parliamentary democracies, some predictions on public good levels are driven by the concentration of political power among 'swing voters'.
} 
Table 1 Variable means by political regime

\begin{tabular}{lrlllll}
\hline Regimes & $\begin{array}{l}\text { GNP } \\
\text { per cap. }\end{array}$ & $\begin{array}{l}\text { Safe } \\
\text { water }\end{array}$ & $\begin{array}{l}\text { Sani- } \\
\text { tation }\end{array}$ & $\begin{array}{l}\text { Road } \\
\text { density }\end{array}$ & $\begin{array}{l}\text { School } \\
\text { enrollm't }\end{array}$ & $\begin{array}{l}\text { Lead } \\
\text { in gas }\end{array}$ \\
\hline $\begin{array}{l}\text { Polity Index } \\
\text { Polity } \geq .5\end{array}$ & 9,429 & 77.6 & 74.9 & 6.96 & 69.8 & 1.72 \\
$\quad$ Polity $<.5$ & 1,279 & 58.6 & 45.5 & 1.62 & 33.5 & 2.37 \\
Red Flags/Green Flags & & & & & & \\
$\quad$ Democracy & 11,261 & 77.8 & 73.6 & 8.35 & 73.9 & 1.55 \\
Mixed & 1,574 & 70.5 & 62.2 & 1.13 & 40.4 & 2.17 \\
Autocracy & 1,315 & 57.8 & 44.3 & 1.94 & 32.2 & 2.42 \\
Descriptive Regimes & & & & & & \\
$\quad$ Democracy & 9,491 & 79.1 & 74.8 & 6.37 & 67.73 & 1.76 \\
Strong Executive & 920 & 58.0 & 43.8 & 2.07 & 35.9 & 2.40 \\
Monarchy & 989 & 68.4 & 56.0 & 0.64 & 35.5 & 2.19 \\
Military Dict. & 1,326 & 53.2 & 39.6 & 0.85 & 26.1 & 2.46 \\
Other & 1,298 & 54.7 & 42.2 & 2.67 & 32.4 & 2.22 \\
\hline
\end{tabular}

Samples: 1970-1992 for GNP, 1990s average for safe water and sanitation, 1970s average for road density, 1980-1995 for school enrollment, 1970-1992 for lead

Variables: GNP per capita in 1995 prices, percent of population having access to safe water and sanitation facilities, road density in $\mathrm{km}$. of roads per square $\mathrm{km}$. land area, secondary school enrollment as percent of school age population, and lead content in grams per gallon of gasoline

Sources: See text

to 1 (democratic); the empirical discussion focuses mainly on results obtained from this measure. The second, termed the Red Flags/Green Flags approach, identifies restrictions on political participation by some groups, an absence of competition for office, the absence of an effective legislature, and similar factors as indicating narrowly controlled political power. The third uses data on government attributes to define standard political regimes: democracy (parliamentary and presidential), strong executive systems, monarchy and military dictatorship. Empirical results are presented for four public goods, safe water, sanitation, roads and public schooling, and for one public bad, lead in gasoline.

As a preview, Table 1 reports summary statistics on political regime, public good indicators and income for the cross-country datasets examined. Detailed definitions for the three sets of regime indicators are given later in the paper. Here, they simply are ordered (top to bottom), from most to least democratic. On average, public good levels are consistently lower (and one public bad level higher) in less democratic than more democratic regimes and the differences are large. While this pattern is consistent with the intuitive argument offered earlier, Table 1 also shows that incomes are consistently lower in less democratic regimes, so public good differences might be due to differences in income. ${ }^{2}$ The results presented later demonstrate that this is not the case; controlling for differences in income and

\footnotetext{
${ }^{2}$ Oil dominated countries (OPEC nations as of 1980 plus Bahrain and Oman) are excluded from Table 1 to keep oil revenues from confounding regime-income comparisons. They are not excluded from estimated models.
} 
other factors, public good provision is consistently and markedly lower under dictatorship than under democracy.

The following section reviews the theoretical and empirical literature on public good provision under dictatorship and democracy. Section 3 develops the model. Sections 4 and 5 discuss the empirical specification and data used. Section 6 reports the empirical results and Sect. 7 concludes.

\section{Related literature}

The literature offers different views on what distinguishes dictatorship from democracy. McGuire and Olson (1996) postulate differences in the objective functions of government leaders. In their view, an autocrat appropriates the government's budgetary surplus and seeks to maximize tax revenue minus government expenditure, recognizing that providing a public good will enhance the tax base. Their 'redistributive democracy' maximizes the welfare of an elite subset of the population, leading to greater public good provision than under dictatorship, but less than a strictly utilitarian bureaucrat would provide. Niskanen (1997) postulates a similar objective function for autocrats, but assumes that democratic leaders maximize the welfare of the median income citizen. He shares McGuire and Olson's conclusion that dictatorships provide fewer public goods than democracies.

Lake and Baum (2001) view public good provision as an exchange process-government provides public goods and transfers in exchange for political support; they trace differences in outcomes to differences in the monopoly power or contestability associated with the position of government leader. They regard contestability as high in a democracy because entry and exit costs are relatively low; the electoral process provides challengers with a safe, relatively inexpensive path to power and deposed incumbents and failed contenders may try again in a later election. Entry and exit costs are much higher under dictatorship; entry may require deposing an all powerful ruler and exit might involve imprisonment or death. Drawing an analogy to ordinary markets, Lake and Baum (2001) expect greater (more competitive) public good levels under democracy than under dictatorship. ${ }^{3}$

In Bueno de Mesquita et al. (2003), policy choices under all forms of government are made to promote the interests of an elite group. What distinguishes dictatorship from democracy is the size of the elite group relative to the population. Essentially the same chain of logic sketched in the introduction leads them to predict low public good levels and large transfers in small elite group regimes (dictatorships) and the opposite in large elite group regimes (democracies).

Although taking varied approaches, these theories all predict lower public good provision under dictatorship than under democracy. Lake and Baum (2001) and Bueno de Mesquita et al. (2003) present empirical evidence supporting this prediction for public education (literacy rates, enrollment rates, persistence to grade level) and public health (immunization rates, access to clean water, infant mortality rates). Bueno de Mesquita et al. (2003) also report that dictatorships offer reduced political and civil liberties, which they regard as public goods. ${ }^{4}$ Two studies report contrary results for spending on public education. Mulligan et al. (2004) found no association between spending for education and Polity scores in a

\footnotetext{
${ }^{3}$ Wintrobe (1990) characterizes two forms of dictatorship, tinpot and totalitarian, in terms of the authoritarian's monopoly position, but does not develop implications for public good provision.

${ }^{4}$ A corollary of Bueno de Mesquita et al.'s theory is that corruption is greater under dictatorship than democracy. They find supporting evidence in data on black market currency exchange premiums and a widely used
} 
cross section formed of 30-year averages of individual country data. Lott (1999) found that totalitarian states spend heavily on education, which he interprets as spending to promote an official ideology. Lott (1999) also finds relatively low public health care in totalitarian states, however, which agrees with the present paper's hypothesis. ${ }^{5}$

To motivate empirical analysis of differences in public good provision between dictatorship and democracy, it is useful to have a single model of government decision-making that incorporates these two cases as alternatives. The next section adapts a model of probabilistic voting from Lindbeck and Weibull (1987) and Lizzeri and Persico (2004) for this purpose. The model's central predictions agree with Bueno de Mesquita et al. (2003); a government controlled by a small, politically powerful group tends to under-provide public goods relative to what a more democratic regime would provide. Here, the nondemocratic regime's behavior results from unevenness in the distribution of political influence among groups and to variations in the responsiveness of different groups to the policy proposals of alternative leaders.

\section{A model of governance and public good provision}

Consider the policy choices of two challengers or parties, A and B, who vie for the support of politically influential groups by making binding promises about how they will organize the government if chosen to lead it. ${ }^{6}$ We focus attention on the narrow question of how the government allocates its budget between public good provision and transfers to specific groups, while recognizing that choosing a leader could also affect the extent of individual freedoms and other fundamental aspects of how society is organized. Any public good provided becomes equally available to everyone in the population. By contrast, a transfer to a specific group is shared equally by the group's members but confers no benefit on those outside the group. Political influence is distributed unevenly across groups. Individuals consult their own consumption-based preferences, as well as idiosyncratic preferences for the challengers, and pledge their political influence to the candidate who offers them higher utility. Both challengers seek to control the government, and control is decided as the equilibrium of a game in which each challenger offers a policy that maximizes expected political influence taking the rival's policy offer as given.

Individuals, indexed by subscript $i$, have identical, concave Cobb-Douglas utility functions for the private good, $c_{i}$, and a public good, $G$ :

$$
U_{i}=\frac{1}{\beta}\left(c_{i} G\right)^{\beta}
$$

corruption index. In turn, more corrupt countries have been linked to low spending on public education and public health by Mauro (1998), to low quality roads and electric distribution systems by Tanzi and Davoodi (1997) and to poor environmental protection outcomes by Welsch (2004), providing indirect corroboration for the link between low public good levels and dictatorship.

${ }^{5}$ Deacon and Saha (2006) review much of the empirical literature on public good provision under dictatorship. Congleton (1992) and Murdoch et al. (1997) examine the related issue of links between governance and participation in international environmental agreements. For empirical evidence on links between public good spending and variations in democratic institutions, see Lott and Kenny (1999), Persson and Tabellini (1999, 2000, 2004), Milesi-Ferretti et al. (2002) and Baqir (2002). Besley and Case (2003) report associations between U.S. state-level spending and democratic institutions.

${ }^{6}$ The assumption of binding commitments clearly is not innocuous. It can be supported by appealing to reputational effects and, in any case, is now a prominent feature in economic models of politics. See Persson and Tabellini (2000, Chapter 4) for discussion of the verifiability and enforceability of policy promises. 
where $\beta<\frac{1}{2} \cdot{ }^{7}$ All individuals face a subsistence constraint for private consumption, $c_{i} \geq$ $\bar{c}>0$, the role of which is made clear shortly. In the following the function (3.1) is referred to as $i$ 's consumption-based utility.

Individuals are also assumed to have idiosyncratic preferences for the candidates. Let $x_{i}$ indicate person $i$ 's idiosyncratic preference for challenger $\mathrm{B}$ relative to challenger $\mathrm{A}$ in the following sense: person $i$ will support A iff $U_{i}^{A}>U_{i}^{B}+x_{i}$ and will support B otherwise, where $U_{i}^{A}$ and $U_{i}^{B}$ represent the maximal consumption-based utility $i$ would enjoy under the policies of challengers A and B, respectively. Individual citizens do not behave strategically, that is, they do not take into account a possible reaction by the challengers to their support. Thus, $i$ will support A iff $x_{i}<U_{i}^{A}-U_{i}^{B}$, support $\mathrm{B}$ if the reverse is true, and toss a coin if the condition is satisfied with equality.

Society is partitioned into $K$ distinct groups, $k=1, \ldots, K$. Let $n_{k}$ indicate the number of individuals in group $k$ and $N$ the number in the total population. The government can offer different transfers to members of different groups. All members of a given group necessarily receive the same transfer, however, and all have identical individual endowments. With these assumptions all members of group $k$ enjoy the same consumption-based utility, henceforth indicated by the subscript $k$.

The idiosyncratic preference terms are known to the corresponding individuals, but are unknown to the challengers, who treat them as draws from known distributions. ${ }^{8}$ The challengers are assumed to regard the idiosyncratic terms as perfectly correlated within groups and, in general, to assign different probability distributions to different groups. The distribution function the challengers assign to group $k$ 's idiosyncratic term is denoted $F_{k}\left(x_{k}\right)$. From a challenger's point of view, the probability that all members of group $k$ will choose to support A, given the policies offered by the two challengers, is

$$
\operatorname{Pr}\left(x_{k}<U_{k}^{A}-U_{k}^{B}\right)=F_{k}\left(U_{k}^{A}-U_{k}^{B}\right) .
$$

The density functions associated with the $F_{k}(\cdot)$ are assumed to be symmetric and to have zero mean; no group is perceived to have a systematic bias in favor of one challenger or the other. $^{9}$

Political influence, denoted $\pi_{k}$ for group $k$, is unevenly distributed. The $\pi_{k}$ terms represent the political power different groups can bring to bear in the selection of a leader. The distribution of the $\pi_{k}$ reflects the basic nature of a society and its system of government and may stem from historical events, traditions, religion, geography, etc. In some countries political influence could be distributed according to wealth. Elsewhere, it might flow exclusively from the command of a military force. ${ }^{10}$ In still others, political influence might

\footnotetext{
${ }^{7}$ Identical Cobb-Douglas exponents are assumed to reduce the notational burden; extensions to different coefficients are obvious.

${ }^{8}$ The $x_{i}$ terms play the same role here as in models of probabilistic voting. The idiosyncratic terms can be interpreted as preferences for personal attributes of the challengers or preferences toward policies to which the challengers cannot credibly commit. Lizzeri and Persico (2001) allow candidates to adopt mixed strategies in policy proposals as a way of generating smooth voter responses to differences in candidates' platforms, an alternative to probabilistic voting.

${ }^{9}$ Lindbeck and Weibull (1987: 279) show that in a model of pure redistribution a bias by one group for a particular party reduces the size of the transfer it receives in equilibrium. Here, we abstract from such systematic bias in order to keep the focus on public good provision.

${ }^{10}$ The Dominican Republic under Trujillo is an example, where political influence resided with a small cadre of military leaders.
} 
result from extraordinary religious authority, membership in a royal family, control of a labor union, or credible adherence to a political doctrine. In a system where voting is the only mechanism for determining political leaders and each member of society has one vote-an ideal democracy - the political influence of different groups matches the size of their membership. In what follows the existing distribution of political influence is taken as given.

Control of the government goes to the challenger whose policy attracts the greater political influence from groups in society. Each challenger offers a public good level, $G$, and a set of group-specific transfers, $c_{k}, k=1, \ldots, K$, that maximizes expected political influence, given the rival's policy offer. ${ }^{11}$ Both proposals must satisfy the economy's budget constraint and each challenger correctly anticipates its rival's policy in equilibrium. Once in power, the winner uses a non-distorting tax to capture the economy's entire endowment, $\omega$, and spends the proceeds on public good provision and transfers.

Denoting A's proposal with a superscript, A's proposed policy maximizes

$$
\Pi^{A}=\sum_{k} \pi_{k} F_{k}\left(\frac{1}{\beta}\left(c_{k}^{A} G^{A}\right)^{\beta}-U_{k}^{B}\right) .
$$

The public good is nonexclusive, so once provided it is equally available to all $N$ citizens. $G$ is also subject to crowding, so the cost of providing it at any particular level is proportional to $N$. The relevant budget constraint for A's policy is therefore

$$
\sum_{k} n_{k} c_{k}^{A}+\alpha N G^{A}=\omega
$$

where $\alpha>0$ is a cost parameter. A's policy maximizes (3.3) subject to (3.4) and the subsistence constraints $c_{k}^{A}-\bar{c} \geq 0, k=1, \ldots, K$. The solution satisfies the first-order conditions

$$
\begin{aligned}
& \pi_{k} F_{k}^{\prime}\left(t_{k}\right)\left(c_{k}^{A} G^{A}\right)^{\beta-1} G^{A}-\lambda n_{k} \leq 0, \quad k=1, \ldots, K \\
& \sum_{k} \pi_{k} F_{k}^{\prime}\left(t_{k}\right)\left(c_{k}^{A} G^{A}\right)^{\beta-1} c_{k}^{A}-\lambda \alpha N=0,
\end{aligned}
$$

where $t_{k} \equiv U_{k}^{A}-U_{k}^{B}, F_{k}^{\prime}$ is the density function of $x_{i}$ for group $k$, and (3.5) holds with equality for group $k$ if $c_{k}^{A}-\bar{c}>0$. B's first-order conditions are similar.

Because they satisfy the linear budget constraint (3.4), the challengers' strategy sets are compact and convex. Continuity of $F(\cdot)$ and $U(\cdot)$ ensures that the payoff functions are continuous. Following Lindbeck and Weibull (1987), the challengers' payoff functions are assumed to be strictly quasi-concave in their strategies. ${ }^{12}$ This guarantees existence of a Nash equilibrium in pure strategies (Fudenberg and Tirole 1991: 34). It also guarantees that each player's best response to an opponent's strategy is unique. It can be shown that a symmetric Nash equilibrium exists and is unique in this game and the remaining discussion

\footnotetext{
${ }^{11}$ This is equivalent to the common assumption in probabilistic voting models that challengers seek to maximize expected plurality. Lindbeck and Weibull (1987: 285-289) provide sufficient conditions under which an alternative objective for challengers, maximizing the probability of obtaining a plurality, leads to the same equilibrium.

${ }^{12}$ An example satisfying this assumption (in the context of strictly quasi-concave utility) is a uniform density function. More generally, concavity of the utility function (3.1) does not guarantee quasi-concavity of the payoff functions without additional restrictions on the form of the cumulative distribution functions, $F_{k}$. Lindbeck and Weibull's (1987) discussion of condition C1 addresses essentially the same issue. Concavity of utility does ensure quasi-concavity of the payoff functions in a neighborhood of a symmetric equilibrium.
} 
focuses on this symmetric outcome. ${ }^{13}$ In this equilibrium we have $t_{k}=0$. While expected political influence is the same for both challengers in equilibrium, one challenger will in general receive greater political support and win. With continuous distribution functions, the probability of a tie is zero.

The ratio $\pi_{k} / n_{k}$ is the political influence per person for group $k . F_{k}^{\prime}(0)$ is the probability (at equilibrium) that a member of group $k$ will switch support from one challenger to the other in response to a small change in the utility differential of their proposals. A large $F_{k}^{\prime}(0)$ indicates that members of group $k$ are highly responsive to consumption-based differences in the rivals' proposals and are less swayed by idiosyncratic factors. It is useful to define $\gamma_{k} \equiv$ $\left(\pi_{k} / n_{k}\right) F_{k}^{\prime}(0)$, which is called group $k$ 's 'effective political influence', where 'effective' means that $\pi_{k} / n_{k}$ is weighted by group $k$ 's responsiveness, $F_{k}^{\prime}(0)$. In what follows, an even distribution of effective political influence across groups is characterized as a democratic political environment, while an uneven distribution of effective political influence is termed non-democratic.

The equilibrium distribution of transfers to groups in society and the level of public good provision are both determined by the distribution of effective political influence. To explore the effect of even versus uneven distributions of influence, we consider a case where there are two groups, $d$ (the disadvantaged) and $e$ (the elite), where $\gamma_{d}<\gamma_{e} \cdot{ }^{14}$ Regarding transfers, (3.5) implies

$$
\frac{c_{e}}{c_{d}} \leq\left(\frac{\gamma_{e}}{\gamma_{d}}\right)^{\frac{1}{1-\beta}} .
$$

This condition holds with equality if both groups receive positive transfers, implying that larger transfers go to groups with greater effective political influence per capita and the size of the disparity in transfers depends on the disparity in political influence. This occurs because in equilibrium a candidate must receive the same increment in expected political support from offering an extra dollar in transfers to either group. With declining marginal utility, this condition can be satisfied only if the group with greater effective political influence receives a larger transfer. ${ }^{15}$ If $\gamma_{d}$ is substantially smaller than $\gamma_{e}$, the subsistence constraint will bind causing $d$ 's transfer to equal $\bar{c}$ and (3.7) will be a strong inequality.

Equation (3.6) links the level of public good provision to the distribution of political influence. Consider first the case where effective political influence for groups $d$ and $e$ is sufficiently similar that both receive positive transfers, and denote the public good level in this case $G^{I}$. Equations (3.5) and (3.6) imply

$$
\frac{n_{e} c_{e}}{G^{I}}+\frac{n_{d} c_{d}}{G^{I}}=\alpha N
$$

\footnotetext{
${ }^{13}$ It can also be shown that this symmetric equilibrium is the unique Nash equilibrium in the case where none of the subsistence constraints binds. Proofs of these points are available from the author.

${ }^{14}$ The number of groups is not a key factor in the following. If one of the groups examined was partitioned into two or more sub-groups, the level of public good provision and transfers per capita would remain unchanged so long as the original group's political influence was divided in the same proportions as its population. The first order condition (3.5) would be unchanged aside from multiplying $\pi_{k}$ and $n_{k}$ by the same factor of proportionality. Equation (3.6) would be unchanged aside from a re-indexing of the groups summed.

${ }^{15}$ The Nash equilibrium in probabilistic voting models of pure transfers corresponds to a social optimum in which each voter's utility is weighted by the group's equilibrium responsiveness (Lindbeck and Weibull 1987). In the current adaptation of this model, the Nash equilibrium corresponds to a social optimum in which individual utility is weighted by the group's effective political influence.
} 
The term $c_{k} / G$ is the marginal rate of substitution of $c$ for $G$ for a member of group $k$ and $\alpha N$ is the marginal cost of providing a unit of $G$, so (3.8) is a Samuelson efficiency condition. Considering the budget constraint, (3.8) implies that society spends one-half of its income on the public good and the other half on consumption, a consequence of CobbDouglas utility with equal exponents. Equation (3.8) therefore implies

$$
G^{I}=\frac{1}{2} \frac{\omega / N}{\alpha}
$$

which can be interpreted as a Cobb-Douglas demand function for the public good. The term $\omega / N$ is economy-wide per capita income and $\alpha$ is price, the per capita cost of increasing $G$ by one unit. In this case the distribution of political influence affects the pattern of transfers and the distribution of income among groups, but has no effect on public good provision. Because all individuals have identical homothetic utility, all groups wish to divide an extra dollar of income between private consumption and the public good in the same way and a political leader can do no better than to fulfill this wish. Accordingly, public good provision depends only on total income and the unit cost of the public good in this case.

To examine effect of a move away from democracy, consider holding group $e$ 's political influence $\left(\pi_{e}\right)$ constant and reducing group $d$ 's influence $\left(\pi_{d}\right)$ to zero. The equilibrium now satisfies

$$
\pi_{e} F_{e}^{\prime}(0)\left(c_{e} G\right)^{\beta-1} G=\lambda n_{e}, \quad \pi_{e} F_{e}^{\prime}(0)\left(c_{e} G\right)^{\beta-1} c_{e}=\lambda \alpha N \quad \text { and } \quad c_{d}=\bar{c} .
$$

Letting $G^{I I}$ represent the public good level for this case, we have

$$
G^{I I}=n_{e} c_{e}=\frac{1}{2} \frac{\omega-n_{d} \bar{c}}{\alpha N}<G^{I},
$$

so the move away from a democratic distribution of political influence reduces provision of the public good. Intuition is gained by expressing $G^{I I}$ as a demand function:

$$
G^{I I}=\frac{1}{2} \frac{\left(\omega-n_{d} \bar{c}\right) / n_{e}}{\alpha N / n_{e}} .
$$

The numerator is the elite's per capita income; it equals the economy's total income less the disadvantaged group's subsistence requirement, per elite. The denominator is the cost of providing a unit of $G$ to a member of the elite; increasing $G$ by one unit $\operatorname{costs} \alpha N$ in total, so the cost to each elite individual is $\alpha N / n_{e}$. Moving the regime away from democracy (by reducing $d$ 's influence to zero) increases the public good price to the elite, but also increases the elite's income, and these two effects work in opposite directions. Given the subsistence constraint and Cobb-Douglas utility, the price effect dominates so the public good level increases.

An intermediate case is one where group $d$ has positive political power, but not enough to receive a positive transfer. Then the first-order condition (3.5) is a strict inequality for group $d$ and $c_{d}=\bar{c}$. Equation (3.6) now implies

$$
n_{e} \frac{c_{e}}{G}+n_{d} \frac{\bar{c}}{G}>\alpha N
$$

The left-hand side is the sum of marginal rates of substitution for both groups and the righthand side is marginal cost. The public good is underprovided relative to what the Samuelson condition requires. It is also lower than would occur if group $d$ were sufficiently powerful to 
receive a positive transfer, but greater than would occur if group $d$ were powerless. Letting $G^{I I I}$ be the corresponding public good level, we have

$$
G^{I I}<G^{I I I}<G^{I} .
$$

The model therefore yields two empirical implications that are worth emphasizing. First, it suggests different public good levels in dictatorships than in democracies, with some presumption for lower provision in dictatorships. The price effect favors lower public good provision in dictatorships because, in a regime that can be controlled by satisfying only a small group, it is costly to gain political support by providing a public good that spreads to the entire population; targeted transfers are a more effective way to spend public funds in this case. There is an income effect working in the opposite direction, however, which makes the net effect an empirical question. It is worth noting that the elite's income response may well be muted if they can satisfy their public good demands by forming exclusive enclaves with separate provision of education and infrastructure or even by living outside the country. ${ }^{16}$ If so, the price effect is likely to dominate.

Second, the model implies that the appropriate income term in an empirical model of public good provision depends on the political regime in power. In a democracy a broad measure of income is appropriate, e.g., GNP per capita. In a non-democratic society, the elite's per capita income is the appropriate measure. Holding constant the appropriate measure of income, the model unambiguously predicts lower public good provision in less democratic regimes.

\section{Empirical specification}

Tests of these predictions are based on the linear specification:

$$
G_{i t}=\gamma_{0} R_{i, t-j}+\gamma_{1} Y_{i, t-j}+\gamma_{2} X_{i, t-j}+\varepsilon_{i t},
$$

where $i$ and $t$ are country and time subscripts, $G_{i t}$ is the public good level, $R_{i t}$ indicates the political regime, $Y_{i t}$ indicates income, the $X_{i t}$ are determinants not captured by the model and $\varepsilon_{i t}$ is an error term. Public good responses are likely to occur with a delay, so the independent variables are lagged. The appropriate $R_{i t}$ variable is an indicator of inequality in the distribution of political power. The appropriate income variable in a democracy is a broad, average income measure, e.g., per capita GNP. The political elite's average income is the appropriate measure in dictatorial regimes, but this is at best difficult to observe. We proceed in two ways here. The first approach is based on expressing the elite's average income, $Y_{e}$, as a function of a country's political regime and its overall per capita income, i.e., $Y_{e}=Y_{e}(R, Y)$. $R$ and $Y$ are then included in the regression model in a flexible way to control for the effect of $Y_{e}$ on public good provision. In estimation the two variables are entered separately and interacted, allowing the public good response to per capita GDP to be different for different regimes. The GDP coefficient has the ordinary demand interpretation in democratic regimes; in nondemocratic regimes it incorporates both price and income components. ${ }^{17}$ The second

\footnotetext{
${ }^{16}$ Mobutu Sese Seko, the former dictator of Zaire, reportedly avoided the capital city of Kinshasa and lived instead in luxurious residences in Europe and South Africa.

${ }^{17}$ While the elite income effect cannot be recovered, the GDP coefficient still provides useful informationthe responsiveness of public good provision to variations in the average citizen's income in democratic and dictatorial regimes.
} 
approach involves incorporating a measure of distributional inequality, the country-level Gini coefficient, into the empirical model.

The $X_{i t}$ variables in (4.1) allow for variations in costs, tastes and other factors not incorporated in the model. Two cost factors examined are population density as a determinant of road networks and urbanization as a determinant of public health services. Further, Alesina et al. (1999) argue that heterogeneous tastes can reduce public good provision by causing disagreement over the specific features public goods embody. Two variables are considered to allow for this possibility: a country's ethnolinguistic fragmentation, the probability that two individuals randomly selected from a given country do not belong to the same language group, and its Gini coefficient.

Either measurement error or endogeneity of $R_{i t}$ would cause the OLS estimate of $\gamma_{0}$, the coefficient of central interest, to be biased and inconsistent. The possibility of measurement error is dealt with by using instrumental variables for regime. ${ }^{18}$ As explained shortly, alternative political regime indicators are available from two distinct data sources. Ten-year lags of regime indicators from one data source are used as instruments for the regime variable reported by the other. While both data sources describe systems of governance, they are compiled by different organizations using different approaches, reducing the possibility that their measurement errors are correlated. ${ }^{19}$ Lagging the instruments deals with the possibility that measurement errors in the two sources are affected by common time-specific factors, e.g., large-scale political or economic events.

Regarding regime endogeneity, Putnam (1993) and Acemoglu et al. (2001) argue that current political institutions for many countries were largely determined centuries ago by historical events, climate, geography, religion, etc. Any such regime determinants that are country-specific and constant over time will be controlled by country fixed-effects. ${ }^{20}$ Nevertheless, regimes do vary over time and a potential concern is that a public good shock might have a causal effect on a country's political regime. Concern about a contemporaneous link from $G$ to $R$ is mitigated by the use of 10-year lags of alternative political indicators as instruments for the current regime. A more subtle concern is that a public good shock in one period might have a contemporaneous effect on regime, and that the public good shock persists. This would lead to a correlation between lagged regime and the current public good disturbance, a problem not solved by the use of lagged instruments for regime. Following Gruber and Hanratty (1995) and Friedberg (1998), we check this possibility by adding the future change in regime (between the current and a future period) as an independent variable and examine its significance. Under the null hypothesis that causality runs from current regime to current public good provision, the coefficient of future regime change is zero. ${ }^{21}$

\footnotetext{
${ }^{18}$ Measurement error would bias $\gamma_{0}$ toward zero, making it more difficult to reject the null hypothesis that regime has no effect on public good provision.

${ }^{19}$ Variables in one dataset (Polity, compiled by Marshall and Jaggers 2000) are based mainly on qualitative judgments about governance, e.g., ordinal measures of the degree of centralization of state authority. Variables in the other dataset (Banks 1997) are focused more on objective attributes of government, e.g., whether or not a legislature can override an executive veto.

${ }^{20}$ Continent-level fixed effects, included in models estimated with cross section data, presumably capture such effects less precisely.

${ }^{21}$ Public goods such as roads, education, health and sanitation presumably affect income, raising a separate endogeneity issue. While any such effects are surely lagged, perhaps by decades, this possibility would remain troublesome if the error terms in (4.1) are correlated over time. Unfortunately, the empirical literature on macroeconomic growth offers few if any suggestions for time-varying instruments for income. In light of this, and the fact that the income coefficient is not the primary interest here, the estimation procedure is not amended to allow for this possibility.
} 


\section{Data}

Five public good indicators are examined. Secondary school enrollment divided by the population of secondary school age is used as an indicator of public education. The sample is a panel of 130 countries over 1980-1996s. Following Hilton and Levinson (1998) and others, the lead content of gasoline (grams per gallon) is used to indicate the strength of environmental protection policy. Regulating lead in gasoline is the most common way to control lead emissions, which cause well-known health problems if ingested. This variable is a rare quantitative measure of environmental protection policy and is available for a cross-country panel. $^{22}$

Data for the remaining three public goods are from cross sections. The percent of the population having access to sanitation facilities and the percent having access to safe drinking water during the mid-1990s (one observation per country) were taken from World Health Organization publications. These variables are reported at irregular intervals for individual countries and often show little or no variation from one year to the next making it inappropriate to treat observations from different years as a panel. Paved and unpaved road mileage from the International Road Federation is used to indicate road infrastructure. Available observations were used to form a cross section giving each country's mean road density (kilometers of road per square kilometer of land) during the 1970s. National defense and police protection are purposely excluded because high levels of these variables might reflect an autocrat's attempt at self-protection rather than public good provision. Quantitative rather than monetary public good measures are used because monetary measures can be inflated in corrupt states where government spending for salaries, construction projects, etc., sometimes represents payoffs to favored groups. ${ }^{23}$

Variations in political regime are represented in three alternative ways. The first measure is a nation's 'Polity' score, formed by subtracting its autocracy score from its democracy score and scaling the result to the unit interval. The underlying data are from the Polity IV database (Marshall and Jaggers 2000) which rates countries based on the degree of political competition, the openness and competitiveness of executive recruitment, and the extent of legislative and judicial constraints on the chief executive. Higher Polity scores represent a more even distribution of political power in the sense of fewer barriers to entry into political life, greater popular control of executive decisions (by effective, popularly elected legislatures) and less exclusive control by political elites.

The second and third methods rely on the more objective governance attributes reported by Banks (1997). These attributes include: the existence or nonexistence of a legislature, the strength of the legislature's powers vis a vis the executive, the exclusion of parties from political participation, whether the chief executive is a civilian, military officer or monarch, whether the chief executive was elected and other factors. ${ }^{24}$

\footnotetext{
${ }^{22}$ Data are available for 48 countries for even years between 1972 and 1992. Thanks are due to Arik Levinson for making these data available.

${ }^{23}$ Lake and Baum (2001: 597) and Tanzi and Davoodi (1997) provide evidence supporting this point.

${ }^{24}$ Gradations of a given political attribute are often reported. For example, a country's legislative effectiveness can be designated as nonexistent, ineffective, partially effective, or effective, and there are criteria for each designation. A legislature is effective if it has significant autonomy, including the power to tax, spend, and override executive vetoes. A legislature is partially effective if it lacks one or more of the powers needed to be an effective legislature. A non-effective legislature is one that cannot implement legislation due to domestic turmoil, cannot meet because the executive prevents it, or is essentially a 'rubber stamp.' A nonexistent legislature is self-explanatory.
} 
The second method for representing regimes uses largely intuitive reasoning to identify indicators of concentrated political power, termed 'red flags'. These are: (i) an ineffective or nonexistent legislature (so the chief executive is all powerful), (ii) a noncompetitive nominating process for the legislature (restricting competition for office to politically powerful groups), (iii) absence of opposition to the party in power, (iv) significant exclusion of political parties, (v) a government controlled by the military, (vi) a non-elected chief executive (military ruler or monarch), (vii) a non-elected legislature, (viii) a parliamentary government in which the premier is not responsible to the legislature, and (ix) the completion of a successful coup d'etat in the preceding year. Attributes indicating broadly dispersed political power, termed 'green flags', are also identified. These are: (i) an elected, effective legislature (with power to tax, spend, and override executive vetoes) in a society that does not exclude major groups from political participation, (ii) direct popular election of the chief executive, and (iii) an elected parliamentary government in which the premier is fully responsible to the legislature. Any country-year observation that has at least one green flag and no red flags is labeled 'Democratic', one with no green flags and at least one red flag is labeled 'Autocratic', and observations falling into neither group are labeled Mixed.

Method three uses data from Banks to categorize observations into five common political regime definitions. A country with an effective or partially effective, elected legislature and an elected chief executive who is either a premier or president is defined to be a Democracy. A government with an elected chief executive but lacking an effective legislature is labeled Strong Executive. A regime in which the chief executive is not elected is called a Military Dictatorship if the chief executive is a military officer and a Monarchy if the chief executive is a monarch. A catchall residual group labeled Other picks up protectorates, communist countries effectively ruled by a party secretary and countries in anarchy. ${ }^{25}$ The concentration of political power is expected to be lower in democracy than in the other regimes; the Other category is unclear a priori, but seems better grouped with the less democratic regimes than with Democracy. ${ }^{26}$

While empirical results are reported for all three governance measures, the Polity measure is emphasized in discussions, robustness checks and hypothesis testing. The second and third measures are examined mainly for corroboration.

\section{Empirical results}

The basic specification for all five public goods includes lagged values of political regime, income and regime-income interactions as independent variables. Country fixed effects are included when estimation is based on cross country panels and continent fixed effects are included for models estimated with cross section data. Additional control variables and alternative estimation strategies were considered for individual public goods, as described in the commentary.

\footnotetext{
${ }^{25}$ Communist governments were assigned to the regimes defined in the text, depending on the details of their systems of governance. Most are characterized by executives who were not elected or elected only indirectly, by chief executives who are either military officers or political party heads (rather than presidents, premiers, or monarchs), and by ineffective legislatures. In the Red Flags/Green Flags scheme, all are categorized as Autocracies. In the Descriptive Regime definitions they are classified as Strong Executive regimes if the chief executive is elected and carries the title of president or premier or Other if the effective chief executive is the head of the communist party.

${ }^{26}$ Refining the democratic regime to examine distinctions between presidential and parliamentary democracy and testing for differences in public good levels is reserved for future research. See Lizzeri and Persico (2001), Milesi-Ferretti et al. (2002) and Persson and Tabellini $(1999,2000)$ for empirical evidence on this question.
} 


\subsection{Provision of safe water, sanitation and road networks}

Estimates for these three public goods, all estimated with cross section data, are presented in Table 2. While there are nine sets of estimates in all, the different methods of characterizing regimes tell essentially the same story: public good provision is significantly greater in more democratic regimes than in less democratic regimes. The Polity index equals 0 for dictatorship and 1 for democracy, so the significant positive Polity coefficients clearly support this conclusion. Coefficients on regime dummies for the two other methods of characterizing regimes provide corroboration. As shown later, the magnitudes of the differences under democracy and dictatorship are dramatic.

When regime-income interactions were included to test for different responses to per capita GDP in dictatorial versus democratic regimes, the interaction coefficients were insignificant due to high correlations between the interaction terms and regime variables. As explained shortly, an alternative procedure was followed to examine this question. Population density and the percentage living in urban areas were considered as additional control variables. In models for safe water and sanitation the percentage of the population living in

Table 2 Provision of safe water, sanitation and road networks
Note: $t$-statistics in parentheses.

Dependent variables are, respectively, the percent of the population with access to safe water and sanitation (ranging from 0 to 100) and the log of road density; income is entered in logs in the equation for roads

Red/Green flags coefficients are jointly significant at $3 \%$ or better in all models; descriptive regime coefficients are jointly significant at $5 \%$ or better in all modes

* Military Dictatorship is the omitted regime

\begin{tabular}{|c|c|c|c|}
\hline $\begin{array}{l}\text { Independent } \\
\text { Variables }\end{array}$ & $\begin{array}{l}\text { Safe water } \\
\text { (1) }\end{array}$ & $\begin{array}{l}\text { Sanitation } \\
\text { (2) }\end{array}$ & $\begin{array}{l}\text { Roads } \\
\text { (3) }\end{array}$ \\
\hline Polity Index & $\begin{array}{l}16.56 \\
(2.5)\end{array}$ & $\begin{array}{l}18.15 \\
(2.2)\end{array}$ & $\begin{array}{l}.8537 \\
(3.3)\end{array}$ \\
\hline Income & $\begin{array}{l}.0013 \\
(1.7)\end{array}$ & $\begin{array}{l}.0013 \\
(1.3)\end{array}$ & $\begin{array}{l}.3040 \\
(2.4)\end{array}$ \\
\hline$R^{2}$ & .39 & .40 & .69 \\
\hline \multicolumn{4}{|c|}{ Red Flags/Green Flags } \\
\hline Democracy & $\begin{array}{l}12.61 \\
(2.5)\end{array}$ & $\begin{array}{l}16.51 \\
(2.7)\end{array}$ & $\begin{array}{l}.6816 \\
(3.4)\end{array}$ \\
\hline Mixed & $\begin{array}{l}9.82 \\
(1.9)\end{array}$ & $\begin{array}{l}13.55 \\
(2.1)\end{array}$ & $\begin{array}{l}.1448 \\
(0.4)\end{array}$ \\
\hline Income & $\begin{array}{l}.0011 \\
(1.4)\end{array}$ & $\begin{array}{l}.0013 \\
(1.4)\end{array}$ & $\begin{array}{l}.3150 \\
(2.5)\end{array}$ \\
\hline$R^{2}$ & .38 & .39 & .69 \\
\hline \multicolumn{4}{|l|}{ Descriptive Regimes* } \\
\hline Democracy & $\begin{array}{l}17.00 \\
(2.0)\end{array}$ & $\begin{array}{l}25.50 \\
(2.7)\end{array}$ & $\begin{array}{l}.4272 \\
(1.8)\end{array}$ \\
\hline Strong Executive & $\begin{array}{l}2.68 \\
(0.3)\end{array}$ & $\begin{array}{l}1.95 \\
(0.2)\end{array}$ & $\begin{array}{l}.1904 \\
(0.8)\end{array}$ \\
\hline Monarchy & $\begin{array}{l}12.60 \\
(1.2)\end{array}$ & $\begin{array}{l}12.93 \\
(1.1)\end{array}$ & $\begin{array}{l}-.2210 \\
(-0.6)\end{array}$ \\
\hline Other & $\begin{array}{l}3.42 \\
(0.4)\end{array}$ & $\begin{array}{l}-0.83 \\
(-0.1)\end{array}$ & $\begin{array}{l}-.2469 \\
(-0.8)\end{array}$ \\
\hline Income & $\begin{array}{l}.0008 \\
(1.1)\end{array}$ & $\begin{array}{l}.0011 \\
(1.3)\end{array}$ & $\begin{array}{l}.4186 \\
(3.5)\end{array}$ \\
\hline$R^{2}$ & .42 & .46 & .70 \\
\hline$N$ (all models) & $88-90$ & $85-87$ & $86-88$ \\
\hline
\end{tabular}


urban areas was found to be a significant control; in the model for roads, population density is a significant determinant. These variables are included in the models of Table 2, but their coefficients were suppressed to simplify the presentation. ${ }^{27}$

To test for regime-specific income responses, countries were grouped into subsamples on the basis of Polity scores and the models of Table 2 were re-estimated for less versus more democratic groups of countries. This yielded the following elasticities of public good provision with respect to per capita GNP, evaluated at subsample means (standard errors in parentheses): ${ }^{28}$

\begin{tabular}{llll}
\hline & Safe water & Sanitation & Roads \\
\hline Polity $<.5$ & .02 & .01 & .34 \\
& $(.02)$ & $(.03)$ & $(.17)$ \\
Polity $\geq .5$ & .08 & .13 & .62 \\
& $(.03)$ & $(.05)$ & $(.18)$ \\
\hline
\end{tabular}

In general, democracies provide safe water, sanitation and road networks at higher levels than dictatorships, in part through differential responses to per capita income.

Ethnolinguistic fractionalization and Gini coefficients were also considered as controls to represent preference heterogeneity; these variables were not retained because they yielded insignificant coefficients and including them substantially reduced sample sizes. ${ }^{29}$ Adding future regime change to check for reverse causation produced an insignificant coefficient for each model and only small changes in other coefficients. Finally, the IV procedure described earlier was used to check for measurement error in the Polity governance indicator; the null hypothesis of no measurement error could not be rejected by Hausman tests for any of the three services.

\subsection{School enrollment}

Table 3 reports results for school enrollment in models with country fixed effects. For each way of defining regimes, results are shown with and without income-regime interactions and the differences in these estimates tell an interesting story. In column (1) both income and Polity are significant and positive when entered separately. A reasonable interpretation of these estimates is income is a strong determinant of school enrollment; political regime, while statistically significant, matters at most 5.6 percentage points, which is modest relative to the sample mean enrollment rate of 0.53. Adding a Polity-income interaction changes the story substantially, as the estimates in column (2) demonstrate. The income coefficient now represents the income response under autocracy (Polity $=0$ ); it is small and actually negative. The sum of the income and interaction coefficients is the income response under democracy (Polity $=1$ ); it is strongly positive and significant. Accordingly, the responsiveness of secondary school enrollment to per capita income is tiny (and negative) under autocracy, but strongly positive under democracy.

\footnotetext{
${ }^{27} \mathrm{~A}$ few observations on access to safe water and sanitation are truncated at $100 \%$; Tobit estimation produced nearly identical results.

${ }^{28}$ Because the subsamples had relatively small numbers of observations, these regressions did not include fixed effects.

${ }^{29}$ Adding an interaction between per capita income and a country's Gini coefficient to allow different income responses in countries where income, and presumably political power, is highly concentrated also reduced sample sizes by over one-half and produced insignificant coefficients for the interaction term.
} 


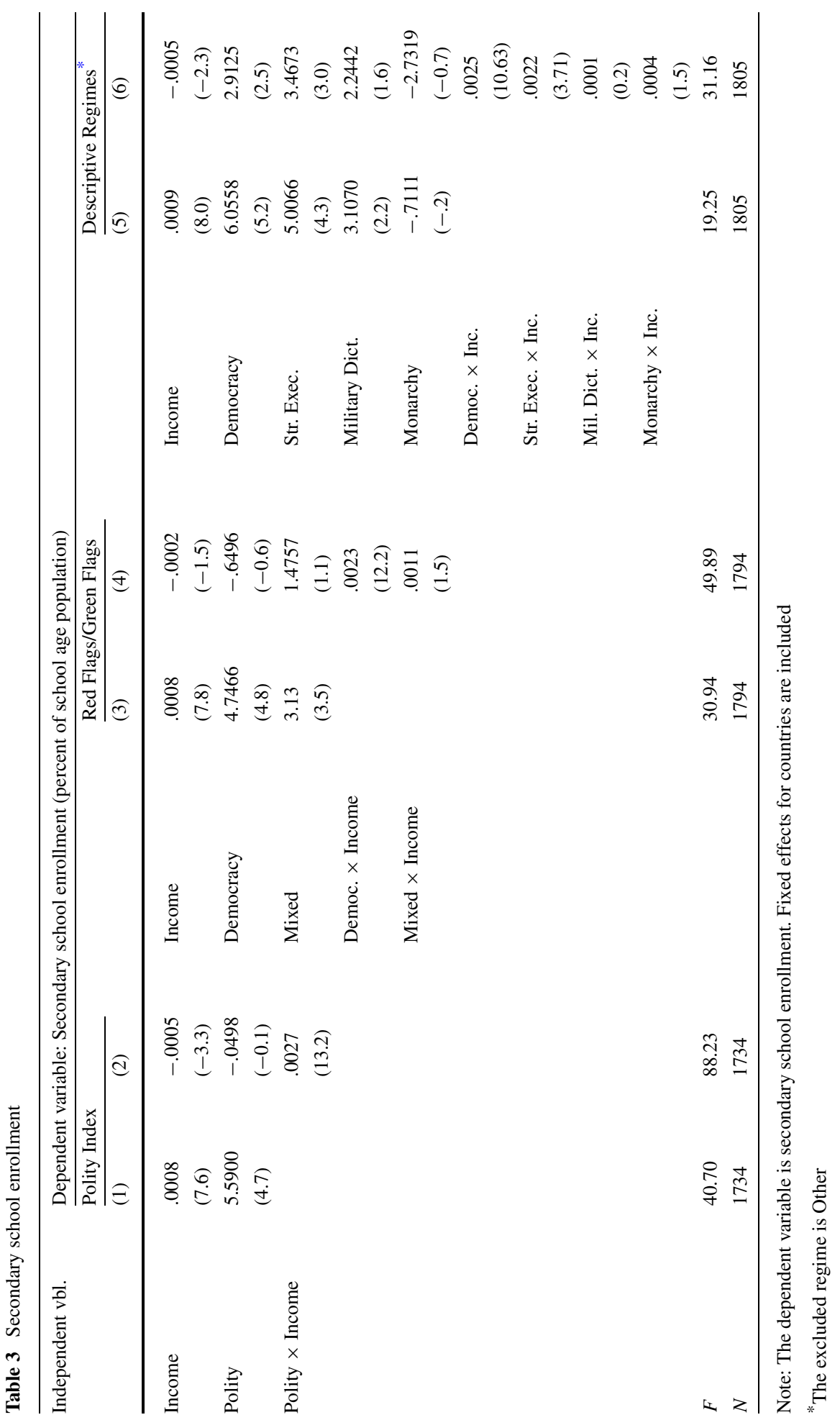


The other two classification schemes for regimes produce similar results. In both sets, the income coefficient represents the income response under the omitted regime, while the sum of the income coefficient and income-regime interaction coefficient is the income response for the corresponding regime. With Red/Green Flags regimes, income is a significant positive determinant of school enrollment under Democracy, but is insignificant for Autocracy and the Mixed regime. With descriptive regimes, the income effect is strong and positive under Democracy and the Strong Executive regimes, but is negative under the remaining three regimes. ${ }^{30}$

Elasticities of secondary school enrollment with respect to per capita GNP were estimated for various regimes. For the Polity estimates the elasticity is 0.372 (s.e. 0.025) under democracy (Polity $>0.9$ ) and -0.037 (s.e. 0.013) under autocracy (Polity $<0.1$ ). (These elasticities were evaluated at mean income and enrollment for countries with Polity scores in the indicated intervals.) The differences produced by other regime indicators are somewhat smaller, but still striking. With Red/Green Flags the elasticity is 0.284 (s.e. 0.02) for Democracy and -0.012 (s.e. 0.01) for Dictatorship. With Descriptive Regimes the elasticities range from 0.234 (s.e. 0.02) for Democracy to -0.032 (s.e. 0.013) for Other.

Re-estimating the Polity models using the IV procedure described earlier to check for measurement error in Polity caused small differences in the coefficients of interest, but the basic pattern was unchanged. ${ }^{31}$ Adding future regime change to check for a causal link from public good provision to regime produced insignificant coefficients and had no substantive effect on other estimates.

\subsection{Lead in gasoline}

Combustion of leaded gasoline is historically the most important source of lead emissions into the environment. Prior to the late 1960s lead was not widely recognized as a serious health problem and was largely uncontrolled. Lead levels consequently did not vary with income or political regime. ${ }^{32}$ Subsequent recognition of health risks led to a general phaseout after 1970, but this proceeded at different rates in different countries. The average lead concentration (grams per gallon) of a country's gasoline is used here as an inverse indicator of the strength of environmental protection policy. The empirical analysis focuses on the rate of phase-out and the central hypothesis is that phase out was slower under dictatorship than democracy.

The lead concentration of gasoline is the dependent variable and income, political regime, regime-income interactions, urbanization and a set of regime-specific trends (year minus 1970 interacted with regime) are independent variables. Because the Red/Green Flags and Descriptive Regimes measures each use several dummy variables, allowing both trends and income responses to be regime-specific makes the model unwieldy. To restore some simplicity, the Polity Index is used to form regime-income interactions in these models. Percent urban population is included because emissions and populations tend to be concentrated

\footnotetext{
${ }^{30}$ When an income-Gini interaction was added to the model of school enrollment as an alternative way of representing the political elite's income under non-democratic regimes, it reduced the sample by more than one-half and did not enter significantly.

${ }^{31}$ Hausman tests for measurement error could not be performed. A few countries had only one observation, so a standard error for the corresponding fixed effect dummy coefficient could not be estimated.

${ }^{32}$ This assertion is based on a regression of lead concentrations on political regime variables and income for the first year in the sample, 1972. The democracy coefficient is negative but insignificant; the $F$ statistic for the entire regression is also insignificant regardless of political regime measure used.
} 
Table 4 Lead content of gasoline

\begin{tabular}{|c|c|c|c|c|}
\hline \multirow{2}{*}{$\begin{array}{l}\text { Independent } \\
\text { Variables }\end{array}$} & \multicolumn{4}{|c|}{ Dependent variable: lead content of gasoline (grams per gallon) } \\
\hline & (1) & (2) & (3) & (4) \\
\hline Income & $\begin{array}{l}-9.02 \mathrm{e}-5 \\
(-3.4)\end{array}$ & $\begin{array}{l}-9.51 \mathrm{e}-7 \\
(-0.02)\end{array}$ & $\begin{array}{l}-9.6 e-6 \\
(-0.2)\end{array}$ & $\begin{array}{l}2.07 \mathrm{e}-6 \\
(0.1)\end{array}$ \\
\hline Trend (year-1970) & $\begin{array}{l}-.0412 \\
(-4.7)\end{array}$ & $\begin{array}{l}-.0203 \\
(-1.8)\end{array}$ & & \\
\hline Polity Index & $\begin{array}{l}-.4817 \\
(-2.9)\end{array}$ & & & \\
\hline Polity Index*Trend & & $\begin{array}{l}-.0348 \\
(-2.6)\end{array}$ & & \\
\hline Polity Index*Income & & $\begin{array}{l}-6.22 \mathrm{e}-5 \\
(-1.5)\end{array}$ & $\begin{array}{l}-5.69 \mathrm{e}-5 \\
(-1.5)\end{array}$ & $\begin{array}{l}-6.87 \mathrm{e}-5 \\
(-1.8)\end{array}$ \\
\hline \multicolumn{5}{|l|}{ Red/Green Flags: } \\
\hline Democracy*Trend & & & $\begin{array}{l}-.0517 \\
(-4.9)\end{array}$ & \\
\hline Mixed*Trend & & & $\begin{array}{l}-.0491 \\
(-4.8)\end{array}$ & \\
\hline Autocracy*Trend & & & $\begin{array}{l}-.012 \\
(-1.2)\end{array}$ & \\
\hline \multicolumn{5}{|l|}{ Descriptive Regimes: } \\
\hline Democracy*Trend & & & & $\begin{array}{l}-.0530 \\
(-5.4)\end{array}$ \\
\hline Strong Executive*Trend & & & & $\begin{array}{l}-.0293 \\
(-2.8)\end{array}$ \\
\hline Military Dictatorship*Trend & & & & $\begin{array}{l}-.0095 \\
(-0.6)\end{array}$ \\
\hline Monarchy*Trend & & & & $\begin{array}{l}-.0388 \\
(-1.4)\end{array}$ \\
\hline Other*Trend & & & & $\begin{array}{l}-.0204 \\
(-1.2)\end{array}$ \\
\hline$F$ & 48.78 & 41.59 & 47.96 & 27.05 \\
\hline$N$ & 458 & 458 & 458 & 458 \\
\hline
\end{tabular}

together when a country is urbanized, making emissions more damaging and implying a negative coefficient. The urbanization coefficients turn out to be negative and marginally significant, confirming this expectation; these coefficients are not reported to simplify the table.

Table 4 reports estimates with fixed effects for countries. Column (1) presents a simple Polity model with no interactions as a starting point. The Polity coefficient is negative as expected and significant, but modest $(-0.48)$ relative to the sample mean (2.08.) The income term is negative and significant and there is a significant downward trend of -0.0412 per year. These estimates suggest that 50 years $(2.08 / 0.0412)$ would be required for the average country to completely eliminate lead, with democracies achieving the result about 12 years $(0.4817 / 0.0412)$ sooner than dictatorships. 
Table 5 Differences in public good provision and environmental protection under most and least democratic regimes

\begin{tabular}{llllll}
\hline Regimes & $\begin{array}{l}\text { Safe } \\
\text { water }\end{array}$ & $\begin{array}{l}\text { Sani- } \\
\text { tation }\end{array}$ & $\begin{array}{l}\text { Road } \\
\text { density }\end{array}$ & $\begin{array}{l}\text { School } \\
\text { enrollm't }\end{array}$ & $\begin{array}{l}\text { Lead } \\
\text { (1992) }\end{array}$ \\
\hline Polity index & & & & & \\
$\quad$ Most Democratic (Polity = 1) & 76.92 & 69.91 & 3.46 & 57.39 & 1.17 \\
Least Democratic (Polity = 0) & 60.35 & 51.75 & 1.47 & 40.00 & 2.27 \\
\% difference (Democ vs. Autoc.) & $27 \%$ & $35 \%$ & $135 \%$ & $48 \%$ & $-49 \%$ \\
\hline
\end{tabular}

Polity-trend and Polity-income interactions are added to the model in column (2) and this leads to a markedly different interpretation. The trend coefficient now represents the trend under dictatorship; it is small $(-0.0203)$ and only marginally significant. The trend under democracy is the sum of trend and Polity-trend interaction terms; it is much stronger $(-0.0551)$ and highly significant. The simple income coefficient in column (2) is the income response under dictatorship; is miniscule and insignificant. The sum of income and Polityincome interaction coefficients is the income response with democracy; it is relatively large $(-6.32 \mathrm{e}-05)$ and statistically significant $(t=2.21)$.

Columns (3) and (4) give results for the Red/Green Flags and Descriptive Regimes, with regime specific trends and income effects included. Only the trends for Democracy and Mixed regimes in column (3) and Democracy and Strong Executive regimes in column (4) are statistically significant and the magnitudes of the trends generally diminish (in absolute value) as one moves from democracy toward autocracy. There are sharp differences in income responses under democracy and dictatorship as well. In general, these differences follow the same pattern as the Polity model estimates: small and insignificant in dictatorial regimes and relatively large and significant under democracy.

The models of columns (1) and (2) were re-estimated using instruments for Polity and its interactions with the trend and with income, to check for measurement error. In all cases, the Hausman test failed to reject the null hypothesis of no measurement error and the magnitudes of the coefficients in models with trend interactions were substantially unchanged. Adding future regime change to the model of column (2) to test for reverse causation, from public good to regime, yielded an insignificant coefficient.

\subsection{Magnitudes of political effects}

The magnitudes of regime effects were assessed by computing predicted values for the dependent variables under the most versus least democratic regimes and comparing means. Table 5 reports results when the Polity index is used to describe political regimes. ${ }^{33}$ The regime effect is weakest for access to safe water, which is also supplied by the private sector so its availability is not solely a government decision. Access to sanitation and secondary school enrollment are, respectively, $35 \%$ and $48 \%$ greater under democracy than under dictatorship. The most dramatic regime effect is for road density, which is over twice as great

\footnotetext{
${ }^{33}$ For safe water, sanitation and roads, the coefficient estimates in Table 2 were used to compute predicted values. For road density, which was expressed in logs in estimation, means of predicted values for log(roads) were computed and antilogs of those means are reported in Table 5. The estimates for schooling and lead include regime-income interactions. Predicted values for different methods of characterizing regimes are available from the author.
} 
under democracy as under dictatorship. Estimates for the public bad, lead in gasoline, pertain to 1992, the last year for which lead data are available. Predicted lead concentrations are nearly twice as high under dictatorship as under democracy. Repeating this exercise for the Red/Green Flag and Descriptive Regime indicators yielded similar results.

\section{Conclusions}

The finding that provision of specific public goods differs sharply between dictatorships and democracies contributes to the growing literature on links between political institutions and policy choices. The size of the regime effect may be most important finding; democratic provision exceeds dictatorial provision by roughly $100 \%$ for environmental protection, more than $100 \%$ for roads, and roughly $25-50 \%$ for safe water, sanitation and education.

The empirical literature linking policy choices to variations in political institutions has focused mainly on total government spending as a public good indicator and on institutional variations within different forms of democracy. Examples are Persson and Tabellini (1999, 2004), Milesi-Ferretti et al. (2002), Besley and Case (2003) and Baqir (2002). Evidence on how democratic institutions influence the provision of specific public goods is relatively scarce, and not always robust when available, e.g., Persson and Tabellini (1999).

What evidence is available on public good provision under dictatorship versus democracy generally agrees with the findings presented here, although there are exceptions. Our findings on school enrollment, safe water and sanitation are in accordance with Lake and Baum's (2001) results on education and public health services. Bueno de Mesquita et al. (2003) did not condition on income and obtained effects for education and health care that agree in sign, but are much larger. Lott's (1999) results on health care provision in totalitarian states agree qualitatively with results presented here if one regards totalitarian and dictatorial regimes as similar. Lott and Kenney's (1999) results on the link between public good provision and the extent of the voting franchise agree with results presented here in the sense that broadening the distribution of political power, by giving women the vote, was followed by increases in state government spending. Lott (1999) and Mulligan et al. (2004) both obtain contrary results on educational spending, possibly because they used a spending measure for education. ${ }^{34}$

An obvious extension is to test the model's prediction that dictatorships place greater emphasis on targeted transfers to politically powerful groups than democracies. These transfers may be accomplished by activities commonly labeled as corrupt, which suggests testing for a positive link between corruption and nondemocratic governance. Bueno de Mesquita et al. (2003) provide some evidence supporting this hypothesis. A second extension follows from the observation that resources devoted to police and armed forces in dictatorial regimes often serve to protect the ruler's hold on power, beyond any public good objective they serve. This suggests testing for greater provision of police and national defense under dictatorship than democracy.

The finding that income responses are regime specific has implications for the role of economic growth as a force in environmental protection. The literature on the environmental Kuznets curve suggests that growth-enhancing policies will eventually result in environmental protection if carried far enough. Judging by results for the three public goods with

\footnotetext{
${ }^{34}$ Also, Lott (1999) includes total government spending as a regressor, so his totalitarianism effect refers to education's share of total spending. Mulligan et al. (2004) take 30-year averages of governance and spending, which may mask associations present in the raw data.
} 
environmental attributes - lead reduction, safe water and sanitation-this proposition is dubious at best for dictatorships. Many of the poor countries that might potentially grow their way into a cleaner environment by following an environmental Kuznets curve are unfortunately autocratic. For these countries, democratization would be the most important step toward a cleaner environment, as well as increased provision of other welfare-enhancing public goods.

More generally, the presence of regime-specific income responses for public goods adds a new dimension to the likely benefits of democratization. If democratization leads to stronger economic growth, as suggested in much of the empirical literature on growth and institutions, democratization would enhance both components of the regime-income interaction term. The estimates produced here indicate that this could lead to dramatic improvements in public education, health care, transportation infrastructure and environmental quality.

Acknowledgements This material is based upon work supported by National Science Foundation Grant SBR-9808696. Ed Basldon and Patricia Silva provided valuable research assistance. Helpful comments were received from Perry Shapiro, Kelly Bedard, Stef Proost, and seminar participants at the following universities: Texas, Michigan, Maryland, Tulane, Emory and Kyoto. Cheng-Zhong Qin deserves special thanks for help with the theory.

Open Access This article is distributed under the terms of the Creative Commons Attribution Noncommercial License which permits any noncommercial use, distribution, and reproduction in any medium, provided the original author(s) and source are credited.

\section{References}

Acemoglu, D., Johnson, S., \& Robinson, J. A. (2001). The colonial origins of comparative development: an empirical investigation. American Economic Review, 91(5), 1369-1402.

Alesina, A., Baqir, R., \& Easterly, W. (1999). Public goods and ethnic divisions. Quarterly Journal of Economics, 114(4), 1243-1284.

Banks, A. S. (1997). A cross-national time series data archive. SUNY Binghampton: Center for Social Analysis. Distributed by Computer Solutions Unlimited, Binghampton, NY.

Baqir, R. (2002). Districting and government overspending. Journal of Political Economy, 110, 1318-1354.

Besley, T., \& Case, A. (2003). Political institutions and policy choices: evidence from the United States. Journal of Economic Literature, XLI, 7-73.

Bohn, H., \& Deacon, R. T. (2000). Ownership risk, investment, and the use of natural resources. American Economic Review, 90(3), 526-549.

Bueno de Mesquita, B., Morrow, J. D., Siverson, R. M., \& Smith, A. (2003). The logic of political survival. Cambridge: MIT.

Congleton, R. D. (1992). Political institutions and pollution control. Review of Economics and Statistics, 74(3), 412-421.

Deacon, R. T., \& Saha, S. (2006). Public good provision by dictatorship: a survey. In A. F. Ott, \& R. J. Cebula (Eds.), The companion in public economics: empirical public economics. Cheltenham: Edward Elgar.

Friedberg, L. (1998). Did unilateral divorce raise divorce rates? Evidence from panel data. American Economic Review, 88(3), 608-627.

Fudenberg, D., \& Tirole, J. (1991). Game theory. Cambridge: MIT.

Grossman, G. M., \& Helpman, E. (1994). Protection for sale. American Economic Review, 84(4), 833-850.

Gruber, J., \& Hanratty, M. (1995). The labor-market effects of introducing national health insurance: evidence from Canada. Journal of Business and Economic Statistics, 13(2), 163-173.

Hilton, F. G. H., \& Levinson, A. (1998). Factoring the environmental Kuznets curve: evidence from automotive lead emissions. Journal of Environmental Economics and Management, 35(2), 126-41.

Lake, D. A., \& Baum, M. A. (2001). The invisible hand of democracy: political control and the provision of public services. Comparative Political Studies, 34(6), 587-621.

Lindbeck, A., \& Weibull, J. W. (1987). Balanced-budget redistribution as the outcome of political competition. Public Choice, 52, 273-97.

Lizzeri, A., \& Persico, N. (2001). The provision of public goods under alternative electoral incentives. American Economic Review, 91(1), 225-239. 
Lizzeri, A., \& Persico, N. (2004). Why did the elites extend the suffrage? Democracy and the scope of government, with an application to Britain's 'Age of Reform'. Quarterly Journal of Economics, CXVI, $707-765$.

Lott, J. R. (1999). Public schooling, indoctrination, and totalitarianism. Journal of Political Economy, 107(6, part 2), s127-s157.

Lott, J. R., \& Kenny, L. W. (1999). Did women's suffrage change the size and scope of government? Journal of Political Economy, 107(6, part 1), 1163-1198.

Magalhaes III, E. (1995). Dictatorships. In F. N. Magill (Ed.), Survey of social science: government and politics series: Vol. 2. Pasadena: Salem.

Marshall, M. G., \& Jaggers, K. (2000). Polity IV project: political regime characteristics and transitions, 1800-1999. College Park: Center for International Development and Conflict Management, University of Maryland.

McGuire, M. C., \& Olson, M. (1996). The economics of autocracy and majority rule: the invisible hand and the use of force. Journal of Economic Literature, 34(1), 72-96.

Mauro, P. (1998). Corruption and the composition of government expenditure. Journal of Public Economics, 69, 263-279.

Milesi-Ferretti, G. M., Perotti, R., \& Rostagno, M. (2002). Electoral systems and public spending. Quarterly Journal of Economics, 117, 609-657.

Mulligan, C. B., Gil, R., \& Sala-I-Martin, X. (2004). Do democracies have different public policies than nondemocracies? Journal of Economic Perspectives, 18(1), 51-74.

Murdoch, J. C., Sandler, T., \& Sargent, K. (1997). A tale of two collectives: sulfur versus nitrogen oxides emissions reduction in Europe. Economica, 64, 281-301.

Niskanen, W. A. (1997). Autocratic, democratic and optimal government. Economic Inquiry, 35, 464-479.

Persson, T., \& Tabellini, G. (1999). The size and scope of government: comparative politics with rational politicians. European Economic Review, 43, 699-735.

Persson, T., \& Tabellini, G. (2000). Political economics: explaining economic policy. Cambridge: MIT.

Persson, T., \& Tabellini, G. (2004). Constitutions and economic policy. Journal of Economic Perspectives, 18(1), 75-98.

Putnam, R. D., (1993). Making democracy work. Princeton: Princeton University Press.

Tanzi, V., \& Davoodi, H. (1997). Corruption, public investment and growth. International Monetary Fund Working Paper 97/139 (October 1997).

Welsch, H. (2004). Corruption, growth and the environment: a cross-country analysis. Environment and Development Economics, 9, 663-693.

Wintrobe, R. (1990). The tinpot and the totalitarian: an economic theory of dictatorship. American Political Science Review, 84(3), 849-72.

Wintrobe, R. (1988). The political economy of dictatorship. Cambridge: Cambridge University Press. 